\title{
PERIDOTITES, GARNETS AND TRACE ELEMENTS: A TELLING TRILOGY ABOUT MANTLE LITHOSPHERE
}

\author{
Dante Canil $^{1}$ \\ ${ }^{1}$ University of Victoria, Canada
}

\section{INTRODUCTION}

This contribution examines a large data compilation of trace element analyses for mantle peridotite whole rocks (WR) and peridotitic garnets. Emphasis is placed on $\mathrm{Al}, \mathrm{Cr}, \mathrm{Sc}, \mathrm{V}$ and $\mathrm{Yb}$ because they are mildly incompatible and their abundances are less affected by chemical modifications impregnated upon typical mantle residues during their residence in the lithosphere, or entrainment in their host magma, as is shown by recent detailed work [1]. Unfortunately, Sc, $\mathrm{V}$ and $\mathrm{Yb}$ are not always analysed in the same or all samples, and interlaboratory inconsistency or accuracy for these elements is not always demonstrable. Al is used as a depletion index because it is immobile and allows for comparison of samples from all states of preservation [2]. Moreover, the behaviour of $\mathrm{Al}$ during partial melting is simple to model empirically, sensitive to $\mathrm{P}$ and coherent with that of $\mathrm{Cr}, \mathrm{Sc}, \mathrm{V}$ and $\mathrm{Yb}$ because these elements all show preference for the same lattice sites in mantle minerals.

There are two major goals of this effort. Firstly, to use the database in concert with experimentally-measured partition coefficients (D) and mantle melting reactions, to distinguish pressure $(\mathrm{P})$ and oxygen fugacity $\left(\mathrm{fO}_{2}\right)$ of melting and potentially the tectonic environment for the formation of lithosphere later sampled 'accidentally' as xenoliths in alkaline magmas. Secondly, simple correlations between garnets and WR data can be used to empirically derive estimates of the degree of depletion and modal mineralogy in the whole rock peridotite represented by garnet xenocrysts.

\section{DATASETS AND CORRELATIONS}

Experimental data in mafic and ultramafic systems shows that $\mathrm{Yb}, \mathrm{Cr}, \mathrm{Sc}$ and $\mathrm{V}$ all partition differently amongst key mantle minerals (gt, sp, cpx) involved during partial melting of the mantle. Of these elements one is potentially redox sensitive, and the order of partition differs, with the general relation: $\mathrm{D}_{\mathrm{gt} / \mathrm{liq}}>$ $\mathrm{D}_{\mathrm{cpx} / \mathrm{liq}} \gg \mathrm{D}_{\mathrm{sp} / \mathrm{liq}}$ for $\mathrm{Sc}$ and $\mathrm{Yb} ; \mathrm{D}_{\mathrm{sp} / \mathrm{liq}}>\mathrm{D}_{\mathrm{cpx} / \mathrm{liq}} \gg \mathrm{D}_{\mathrm{g} t / \mathrm{liq}}$ for V; $\mathrm{D}_{\text {sp/liq }}>>\mathrm{D}_{\mathrm{cpx} / \mathrm{liq}}>\mathrm{D}_{\mathrm{gt} / \mathrm{liq}}$ for Cr. Chemical data from peridotite melting experiments [3-6] show that bulk $\mathrm{D}_{\mathrm{Cr} / \mathrm{Al}}$ between residue/melt decreases with increasing pressure from 1 to greater than $3 \mathrm{GPa}$. Thus, correlations amongst $\mathrm{Yb}, \mathrm{Cr}, \mathrm{Sc}, \mathrm{V}$ and $\mathrm{Al}$ may be illustrative of the effects of $\mathrm{P}$ and $\mathrm{fO}_{2}$ on melting to form a residue.

Covariation of $\mathrm{Cr}$ with $\mathrm{Al}$ shows essentially no change in $\mathrm{Cr}$ content with increasing depletion, irrespective of peridotite sample type or facies. The implication is that all peridotites (both gt- and sp-facies) mainly represent residues of melting at $\mathrm{P}<3.0 \mathrm{GPa}$ within the stability field of spinel. Notable scatter at less than $2 \mathrm{wt} \% \mathrm{Al}_{2} \mathrm{O}_{3}$ is restricted to the xenolith datasets, and ascribed to a 'nugget' effect for spinel, a modally minor phase but one that dominates the budget for $\mathrm{Cr}$ and is poorly sampled in smaller specimens.
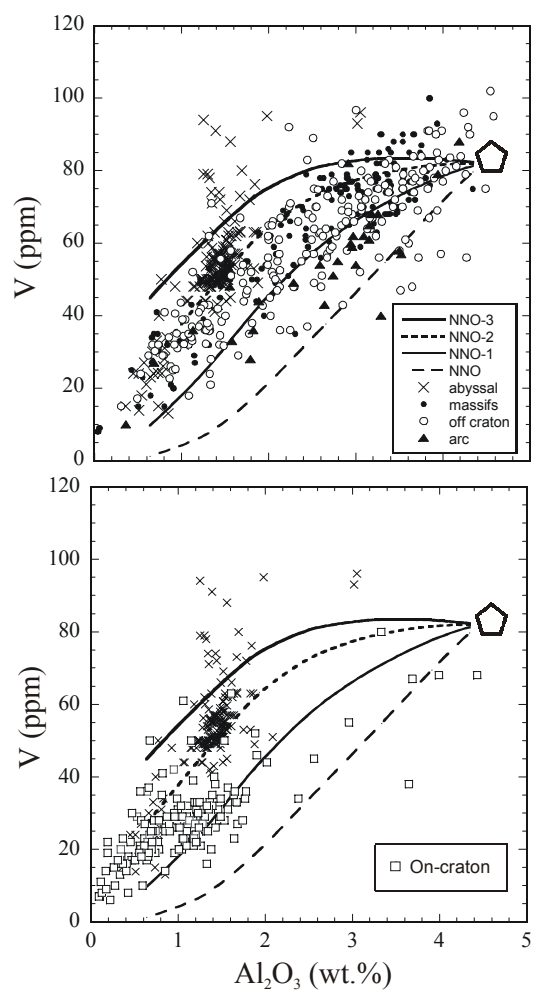

Covariation between $\mathrm{V}$ and $\mathrm{Al}$ above shows a large proportion of cratonic peridotites are distinct from many other peridotite types. One interpretation based on modeling of experimental partitioning data for $\mathrm{V}$ is that most cratonic peridotites were formed by melt extraction at a higher $\mathrm{fO}_{2}$ than that during formation of other kinds of continental and oceanic mantle 
lithosphere, perhaps in a convergent margin setting [7]. The modeling can at this point only be illustrative because the distribution of all sample types in V-Al space in terms of their 'paleoredox' during formation requires better and more internally consistent analytical data for $\mathrm{V}$.

Covariations of $\mathrm{Sc}$ with $\mathrm{Al}$ show an opposite sense/trend than would be predicted by trends with $\mathrm{V}$ and $\mathrm{Cr}$. The abyssal peridotite array does not extrapolate to primitive mantle values for $\mathrm{Sc}$, but spreads along a distinct trend depleted in Sc for a given Al content, unlike the case for $\mathrm{V}$. The reasons for this are not presently understood, but may be analytical, or may concern the different behavior of Sc relative to $\mathrm{V}$, $\mathrm{Cr}$ and $\mathrm{Al}$ in the oceanic mantle sampled by abyssal peridotites.

The correlation of $\mathrm{Al}$ with $\mathrm{Yb}$ in mantle rocks is well known and utilized [8-10]. As shown below, however, this correlation is irrespective of whether samples are gt- or sp-facies, xenoliths, massifs or abyssal peridotites. Most interesting is that at a given level of depletion (Al), few gt-bearing mantle samples show the higher $\mathrm{Yb}$ expected for residues produced in the gt stability field because of the large $\mathrm{D}_{\mathrm{gt} / \text { liq }}$ for $\mathrm{Yb}$. This feature further amplifies the case that garnet is not present during melting to form the residue represented by almost all of these rocks.

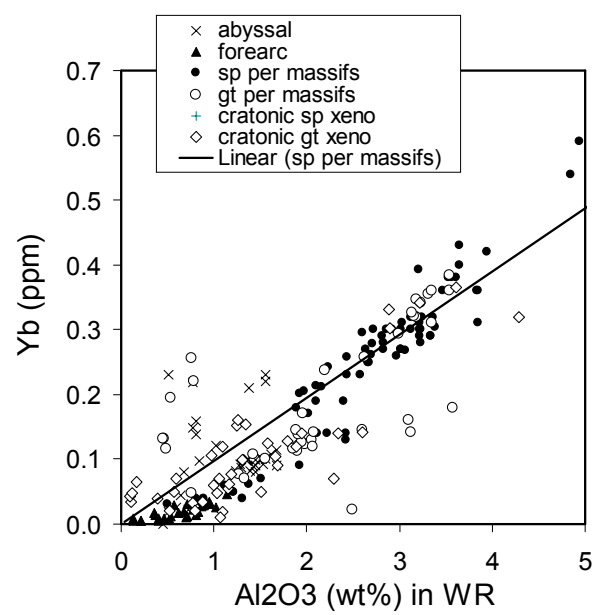

Thus, an over-arching observation for all peridotites examined is that almost all mantle peridotites, irrespective of current facies (gt, plag or sp) or sample type (abyssal, orogenic massif, on/off craton xenolith) likely started life as lithosphere in the spinel facies. A similar conclusion has been made on the basis of high $\mathrm{Cr} / \mathrm{Al}$ in mantle garnet compositions [11-13].
The correlation of $\mathrm{Yb}$ with $\mathrm{Al}$ in peridotites has a second significance when considered in concert with the chemical systematics of garnet. More than $70 \%$ of the $\mathrm{Yb}$ in whole rock analyses of garnet peridotites is contained in garnet [1]. For this reason, $\mathrm{Yb}$ in garnet $\left(\mathrm{Yb}_{\mathrm{Gt}}\right)$ may serve as a simple proxy of $\mathrm{Yb}$ in a whole rock garnet peridotite $\left(\mathrm{Yb}_{\mathrm{WR}}\right)$, as shown below by data in studies of garnets and coexisting WR $[1,14]$.

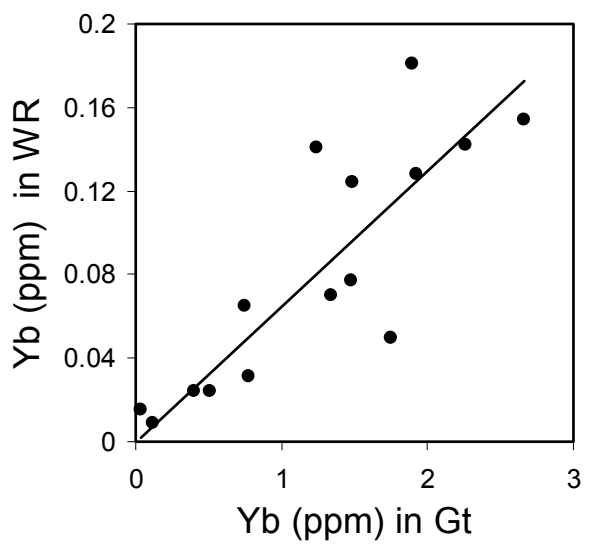

Using the correlations of $\mathrm{Yb}_{\mathrm{Gt}}$ with $\mathrm{Yb}_{\mathrm{WR}}$, and the latter with $\mathrm{Al}_{2} \mathrm{O}_{3 \mathrm{WR}}, \mathrm{Yb}_{\mathrm{Gt}}$ can potentially be used to estimate the whole rock $\mathrm{Al}_{2} \mathrm{O}_{3}$ content of a peridotite from which it was derived. Furthermore, as shown below $\mathrm{Al}_{2} \mathrm{O}_{3 \text { WR }}$ correlates very well with modal gt in wellcharacterized 'large' peridotite samples [1, 15-17].

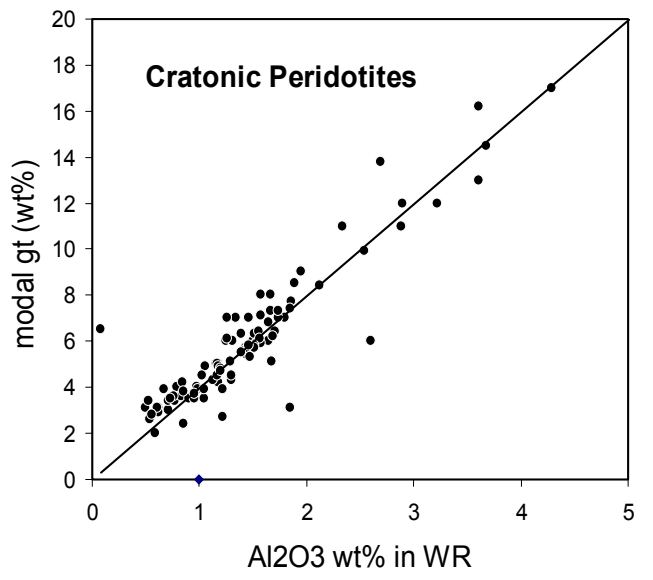

\section{APPLICATION}

From these correlations, a multitude of potential applications follow. Coupled with Ni-thermometry [18, 19], garnets may be viewed in a spatial context to derive quantitative estimates of the degree of depletion 
and modal abundance of garnet in sections of subcontinental lithosphere sampled by kimberlites. Estimates of whether a given garnet xenocryst is 'harzburgitic' $(<5 \% \mathrm{cpx})$, or lherzolitic $(>5 \% \mathrm{cpx})$ could also be made using the empirical correlations. This improves on, or obviates, the classification of mantle garnets based on $\mathrm{Ca}-\mathrm{Cr}$, which is obscured by $\mathrm{P}-$ T-X effects [20]. Ultimately, peridotite compositions constructed from these empirical correlations in garnet xenocryst datasets can be combined with requisite mineral physical parameters to estimate the density and/or seismic velocity of mantle sections, for comparison with similar data derived from different approaches to garnet xenocrysts [21, 22] and from seismology.

The above correlations are applied to internally consistent trace element analyses determined by LAICPMS on garnet suites from 18 kimberlites in the Slave, Wyoming, Hearne, Superior and Yavapai Mazatzal Provinces in North America [23-25]. We construct lithospheric sections of $\mathrm{Al}_{2} \mathrm{O}_{3 \mathrm{WR}}$, and modal gt with depth in the subcontinental lithosphere.

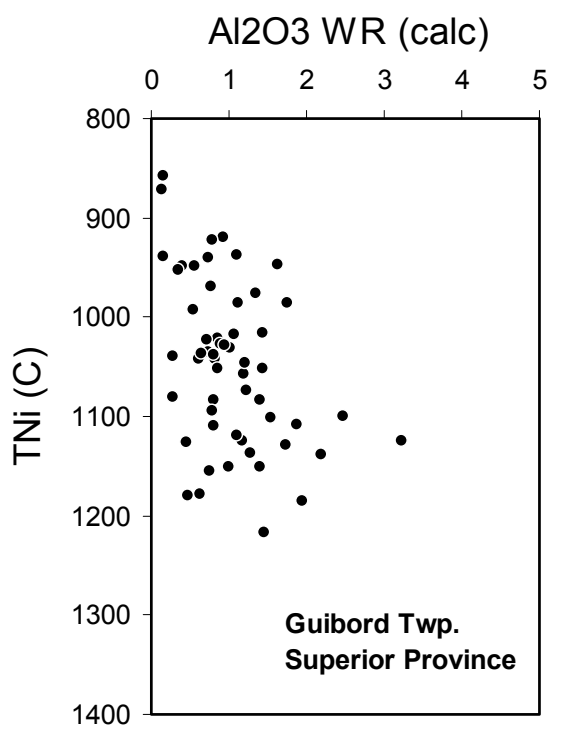

One example from a kimberlite in the Superior Province [25] is shown above for illustrative purposes. We find that garnet xenocryst suites in nearly all kimberlites examined show an upper lid of very depleted lithosphere $\left(<1 \% \mathrm{Al}_{2} \mathrm{O}_{3 \mathrm{WR}}\right)$ but less depleted with depth to values approaching the primitive upper mantle, consistent with observations made from olivine compositions in the mantle [21].

\section{REFERENCES}

1 S.S. Schmidberger and D. Francis, J. Petrol. 42, 1095-1117, 2001.

2 J.E. Snow and H.J.B. Dick, Geochim. Cosmochim. Acta 59, 4219-4235, 1995.

3 M.B. Baker and E.M. Stolper, Geochimica et Cosmochimca Acta 58, 2811-2827, 1994.

4 T.J. Falloon, D.H. Green, H.S.C. O'Neill and W. Hibberson, Earth Planet. Sci. Lett. 152, 149-162, 1997.

5 J.A.C. Robinson, B.J. Wood and J.D. Blundy, Earth and Planetary Science letters 155, 97-111, 1998.

6 M.J. Walter, Journal of Petrology 39, 29-60, 1998.

7 D. Canil, Earth Planet. Sci. Lett. 195, 75-90, 2002.

8 E. Jagoutz, H. Palme, H. Baddenhausen, K. Blum, M. Cendales, G. Dreibus, B. Spettel, V. Lorenz and H. Wanke, in: 10th Lunar and Planetary Science Conference, pp. 2031-2050, 1979.

9 W.F. McDonough and S.S. Sun, Chem. Geol. 120, 223-253, 1995.

10 H. Palme and K. Nickel, Geochim. Cosmochim. Acta 49, 2123-2132, 1985.

11 D. Canil and K. Wei, Contributions to Mineralogy and Petrology 109, 421-430, 1992.

12 T. Stachel, K.S. Viljoen, G. Brey and J.W. Harris, Earth and Planetary Science Letters 159, 1-12, 1998.

13 S.E. Kesson and A.E. Ringwood, Chemical Geology 78, 97-118, 1989.

14 D.G. Pearson and G.M. Nowell, Phil. Trans. R. Soc. Lond. 360, 2382-2410, 2002.

15 F.R. Boyd, P.H. Nixon, D.G. Pearson and S.A. Mertzman, Contrib. Mineral. Petrol. 113, 352-366, 1993.

16 F.R. Boyd, N.P. Pokhilenko, D.G. Pearson, S.A. Mertzman, N.V. Sobolev and L.W. Finger, Contributions to Mineralogy and Petrology 128, 228-246, 1997.

17 F.R. Boyd, Earth and Planetary Science Letters 96, 15-26, 1989.

18 D. Canil, Contributions to Mineralogy and Petrology 136, 240-246., 1999.

19 W.L. Griffin, D.R. Cousens, C.G. Ryan and G.F. Suter, Contrib Mineral Petrol 103, 199-202, 1989.

20 F.E. Brenker and G.P. Brey, Journal of Metamorphic Geology 15, 581-592, 1997.

21 O.F. Gaul, W.L. Griffin, S.Y. O'Reilly and N.J. Pearson, Earth Planet Sci. Lett. 182, 223-235, 2000.

22 Y.H. Poudjom Djomani, S.Y. O'Reilly, W.L. Griffin and P. Morgan, Earth Planet. Sci. Lett. 184, 605$621,2001$.

23 G.B. Carbno and D. Canil, J. Petrol. 43, 129-142, 2002.

24 D. Canil, D.J. Schulze, B.C.J. Hearn, D.C. Hall and S.M. Milliken, Can. J. Earth Sci. in press, 2003.

25 K. Scully, D. Canil and D.J. Schulze, Chem. Geol., submitted. 